\title{
A new species of Aeschynomene (Papilionoideae: Dalbergieae) from Oaxaca, Mexico
}

\section{Una especie nueva de Aeschynomene (Papilionoideae: Dalbergieae) de Oaxaca, México}

\author{
Alfonso Delgado-Salinas ${ }^{\bigotimes}$ and Solange Sotuyo \\ Universidad Nacional Autónoma de México, Instituto de Biología, Departamento de Botánica, Apartado Postal 70-233, 04510 Coyoacán, México D. F., \\ México. \\ \adelgado@ibiologia.unam.mx
}

\begin{abstract}
Aeschynomene sousae Rudd ex A. Delgado et Sotuyo is described from southern Oaxaca, Mexico, where it is likely endemic to the northeast mountains of the Isthmus of Tehuantepec. It is a member of series Scopariae of subgenus Ochopodium, and morphologically similar to A. nicaraguensis from which it differs mainly in having ovate to lanceolate, larger bracteoles, bright yellow flowers with a reddish arched, insect guide-mark on the interior face of the standard petal, in the fusion of the 2 wing petals along part of their upper margins and also fruits bearing 1 to 2 seeds.
\end{abstract}

Key words: Aeschynomene, Leguminosae, Mexico, Oaxaca, Ochopodium, systematics.

\begin{abstract}
Resumen. Se describe la especie Aeschynomene sousae Rudd ex A. Delgado et Sotuyo del sur de Oaxaca, México, que parece ser endémica de las montañas al noreste del Istmo de Tehuantepec. Es miembro de la serie Scopariae del subgénero Ochopodium y morfológicamente similar a A. nicaraguensis, de la cual principalmente se diferencia por tener bractéolas ovado-lanceoladas y más largas, flores amarillo brillantes, con un arco rojizo en la cara interior del estandarte, en la fusión parcial de las alas por el margen superior y también por contar con frutos de 1 a 2 semillas.
\end{abstract}

Palabras clave: Aeschynomene, Leguminosae, México, Oaxaca, Ochopodium, sistemática.

\section{Introduction}

The most recent comprehensive treatment of the genus Aeschynomene is that of Rudd (1955), although subsequently published supplementary papers, particularly on the series Scopariae Rudd (Rudd 1975, 1989). According to Rudd (1955) plants of series Scopariae are characterized by their shrubby habit, with leaflets usually symmetrical with a central vein. Of the approximately 25 species of series Scopariae occurring in the New World (Baja California, Mexico southward to Andean Peru, and in the mountains of the Guyanas and Brazil) 12 are found in western and southern Mexico, and only A. nicaraguensis (Oerst.) Standl. inhabits northern Central America (Rudd, 1955; Fernandes 1996), the remaining species of the series are restricted to South America.

During research into the phylogenetic systematics and phylogeography of the genus Aeschynomene sensu lato, a particular set of specimens classified as belonging to the series Scopariae of subgenus Ochopodium and distributed in the Mexican state of Oaxaca has proven to be morpho-

Recibido: 02 agosto 2011; 09 diciembre 2011 logically distinct and considered worth describing as a new species. It is appropriate to also mention that the species was earlier recognized as new based on herbarium specimens studied by Dr. Rudd in the late 1970's, when the Legumes of Oaxaca project started under the leadership of Dr. Mario Sousa. The new taxon is described and illustrated below.

\section{Materials and methods}

A total of more than 20 herbarium specimens of Aeschynomene sousae, and A. nicaraguensis, that possessed a range of mature vegetative, floral, and fruiting characters were sampled. The description of $A$. sousae is based on herbarium specimens from the Herbario Nacional de México (MEXU), and on living material collected in Oaxaca, Mexico, in October 2010 (under collecting permit SEMARNAT-03-039, Dirección General de Gestión Forestal y de Suelos, SEMARNAT). Observations of the leaflet mucro were carried out under a Leica microscope (Z16 APO-A). For observations of external pollen features, non-acetolyzed pollen grains were mounted on stubs, sputter coated with gold in an EMITECH K 550, and studied under a Hitachi S-2460N scanning electron microscope (SEM) at $15 \mathrm{KV}$. 


\section{Description}

Aeschynomene sousae Rudd ex A. Delgado et Sotuyo, sp. nov. Type: Mexico. Oaxaca: Tehuantepec District. Municipio Santo Domingo Tehuantepec, a $15 \mathrm{~km}$ sobre la desviación Buenos Aires a San Miguel Tenango, selva baja caducifolia, $700 \mathrm{~m}, 16^{\circ} 18^{\prime} 48.2^{\prime \prime} \mathrm{N}, 95^{\circ} 30^{\prime} 10.7^{\prime \prime} \mathrm{W}$, 19 Oct 2010 (fl), Delgado-Salinas y Sotuyo 2732 (holotype: MEXU; isotypes: GH, K, MO, NY, TEX, US). Figures 1, 2.

A. nicaraguensis (Oerst.) Standl. similis, sed differt petiolis inflorescentiisque trichomatibus basi tuberculata munitis, bracteolis longioribus (2-3 mm vs. ca. $1.5 \mathrm{~mm}$ ), lanceolatis (vs. ovatis), floribus aureis vel aurantiacis vs. obscure aurantiacis), vexillo intus rubro-lineato (vs. brunneo-lineato vel purpureo-lineato), corollae alis ad marginem superiorem connatis, fructibus 1-2-articulatis (vs. 3-articulatis).

Shrub up to $2.50 \mathrm{~m}$ tall from a ramified taproot, with few flexible, striate, simple or branched stems, young ones pigmented red, mature ones grayish, lenticels conspicuous, whole plant copiously short-pilose at least when young, with pilose trichomes mostly spreading (appressed on the leaflets), the young growth sometimes canescent; glandbased setae usually intermixed and present on petioles, inflorescence axes, margins of bracts, bracteoles and calyx teeth, numerous or few. Leaves pinnate, $4.5-11 \mathrm{~cm}$ long; stipules subulate to lanceolate, slightly falcate, $5-7 \mathrm{~mm}$ long, striate, tardily brownish and caducous, petiole 1-1.7 $\mathrm{cm}$ long, pilose to hirsute, with short-glandular setae intermixed; leaves mostly with 16-22 leaflets, in alternate or subopposite pairs, leaflets oblong to obovate, 2.5-10 (-15) $\mathrm{mm}$ long, ca. $10 \mathrm{~mm}$ wide, base oblique, rounded, apex obtuse, mucronate (occasionally mucros have secretions from their tips), membranous to chartaceous, glabrous to short-pilose. Inflorescences axillary, commonly panicles, with up to 8 axes, 2-8 cm long, each axis 3-5 flowered, often also with terminal leafless panicles; floral bracts ca. 1 $\mathrm{mm}$ long, with gland-based setae, persistent; pedicels ca 5 $\mathrm{mm}$ long, with antrorse white hairs and gland-based setae; bracteoles ovate-lanceolate, 2-3 $\mathrm{mm}$ long, ca. $1 \mathrm{~mm}$ wide, with gland-based setae, striate (5-10-veined), persistent. Flower papilionaceous, ca. $1 \mathrm{~cm}$ long; calyx 5-toothed, 4-4.5 mm long, 3.5-4 mm wide, tube $2.5 \mathrm{~mm}$ long, sparsely pilose, teeth triangular, subequal, $1.5 \mathrm{~mm}$ long, $1.5 \mathrm{~mm}$ wide, lower tooth ca. $2 \mathrm{~mm}$ long, gland-based setae present along the margins; corolla bright yellow to orange-yellow, standard dorsal face with reddish lines, pilose, internal face having an arched basal reddish insect guide-mark surrounding a central dull yellow area; 8-10 mm long, 8-10 mm wide, slightly auriculate towards the claw, claw ca. $1 \mathrm{~mm}$ long; wings spathulate, distally pilose, auricles broad and oblong above $2 \mathrm{~mm}$ claws, laminas connate along adaxial margins for $3 \mathrm{~mm}$ from the auricle towards the apex, lightly marked with reddish veins; keel slightly beaked, auricles and claws as for the wings, laminas with distal margins fused; androecium of 10 stamens, monadelphous, staminal tube with a narrow fenestra at base of adaxial margins and with an open slit at abaxial or lower edges of staminal sheath, filaments alternately longer and shorter, anthers oblong, basifixed to medfixed, pollen tricolporate, prolate, exine with coarsely pitted, reticulate sculpturing; endoapertures covered with operculi; gynoecium sparsely pilose, 2-ovulate, style angled at base, filiform, stigma apical. Fruit chartaceous, 1-2-articulate, the articles 10-15 mm long, ca $10 \mathrm{~mm}$ wide, valve reticulate-veined, glabrous to short-pilose, with patent hairs on the sutures; stipe 6-10 $\mathrm{mm}$ long, pilose, with gland-based setae intermixed. Seeds oblong, brown, ca $6 \times 4 \mathrm{~mm}$.

Distribution, ecology, and phenology. A. sousae is restricted to the districts of Yautepec and Tehuantepec, in the highly diverse physiographic and floristic province of the Isthmus of Tehuantepec, Oaxaca (Sousa et al. 2004), at elevations from $45-1085 \mathrm{~m}$. It is usually found in small populations, in seasonally dry tropical forests and in oak forests, on limestone cliffs and outcrops, frequently along creeks and ravines of the Sierra Madre del Sur. Flowering ocurrs from August to November and fruiting from October to November.

Additional specimens examined. Mexico. Oaxaca. Tehuantepec District. Municipio Santo Domingo Tehuantepec, Santa Lucía, al O de El Limón, a 17 km al O de Tehuantepec, 19 Ags 1985, C. Martínez R. 1377 (MEXU); 15 $\mathrm{km}$ al SO de Buenos Aires, hacia Tenango, entrando por Hierba Santa, $10 \mathrm{~km}$ al NO de Tehuantepec, 15 Sep 1985, R. Torres C. 7366 (MEXU; MO); El Manguito al S de El Limón, a $11.1 \mathrm{~km}$ al SW de la entrada a Buenos Aires, 25 Nov 1983, R. Torres C. 4154 (MEXU; MO). Municipio San Pedro Huamelula, Cerro Jabalí, 16 3'31.1' N, 9542'12.8" W, 25 Sep 2009, J. Leyva Márquez 626 (MEXU); Piedra, 16'1'19.9” N, 95'42'19.1” W, 12 Oct 2010, S. Molina Bende 498 (MEXU). Yautepec District. Municipio Asunción Tlacolulita, $2 \mathrm{~km}$ al E-NE de La Reforma, 26 Oct 1977, M. Sousa et al. 8615 (MEXU); Los Tunillos, a 2 km al E-NE de La Reforma, carretera Oaxaca-Tehuantepec, 26 Oct 1976, M. Sousa et al. 6572 (MEXU); Los Tunillos, a $2 \mathrm{~km}$ al NE de La Reforma, 18 Sep 1978, M. Sousa et al. 9486 (MEXU); Municipio de San Carlos Yautepec, Río de Sanja, a $11 \mathrm{~km}$ al N de Ayuta, camino a Guadalupe Victoria, 155'35" N, 9551'58” W, 22 Nov 1999, E. Martínez S. et al. 33241 (MEXU).

Etymology. Dr. Velva Rudd recognized this taxon as a new species on identification labels in herbaria, and named it for Mario Sousa Sánchez. Unfortunately the name was 


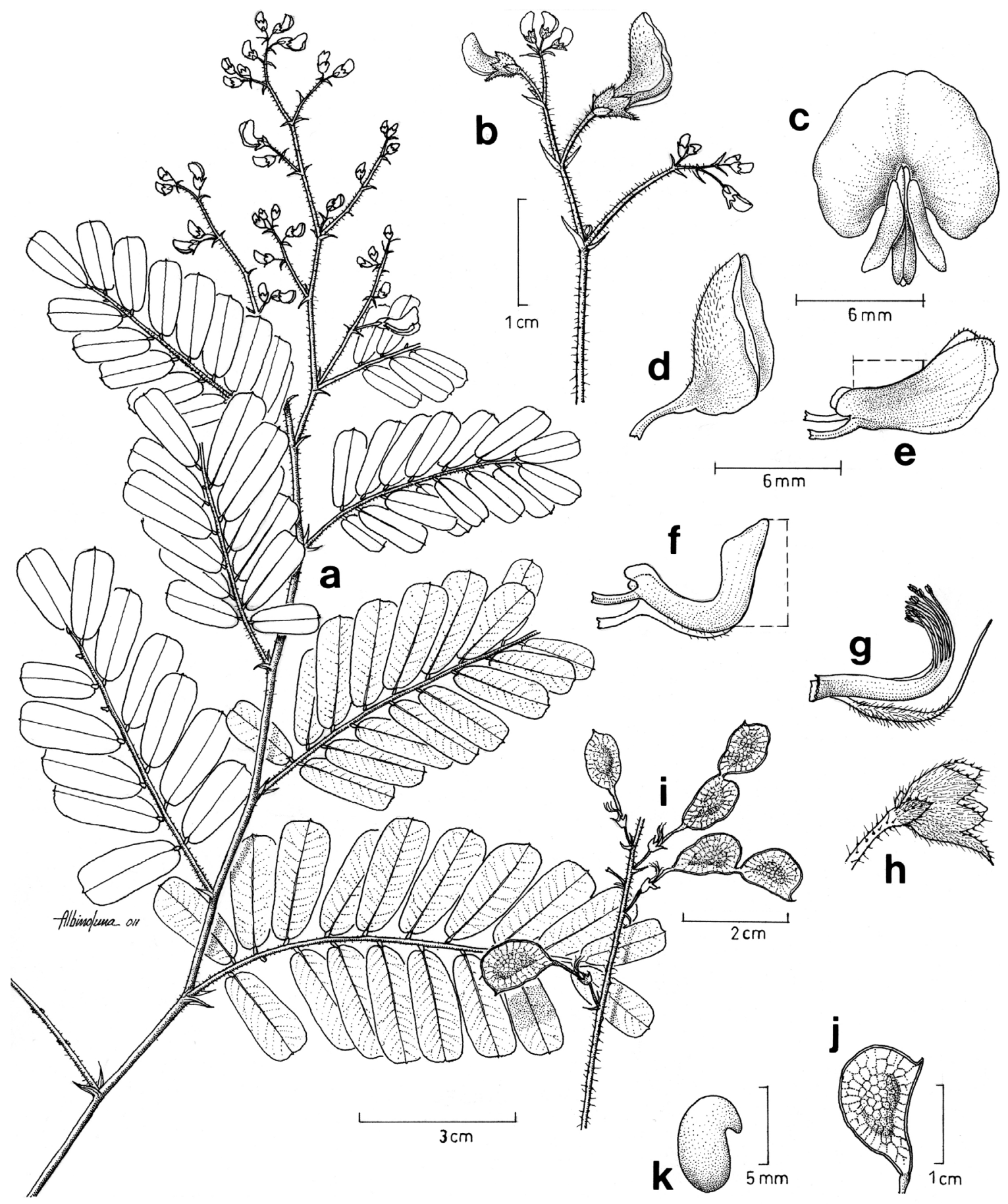

Figure 1. Aeschynomene sousae Rudd ex A. Delgado et Sotuyo. a, plant habit, showing inflorescences with flower buds, and flower at anthesis; b, part inflorescence, (a, b drawn from Cipriano Martínez 137, MEXU); c, flower, front view; d, standard, side view showing hairs on the dorsal surface of the lamina; e, wing petals, showing auricles above claws and upper margin connation (dotted line); f, beaked keel, distal portion fused (dotted line); g, androecium, staminal tube and gynoecium; h, calyx and pedicel, calyx tube with a pair of bracteoles at base, the pedicel covered with gland-based setae; i, infrutescence, fruits stipitate, each with 1-2 articles; j, fruit article, with glabrous, translucent and veined valve; k, seed, side view (c-k drawn from Mario Sousa S. 8615, MEXU). Figure by Albino Luna (IBUNAM). 


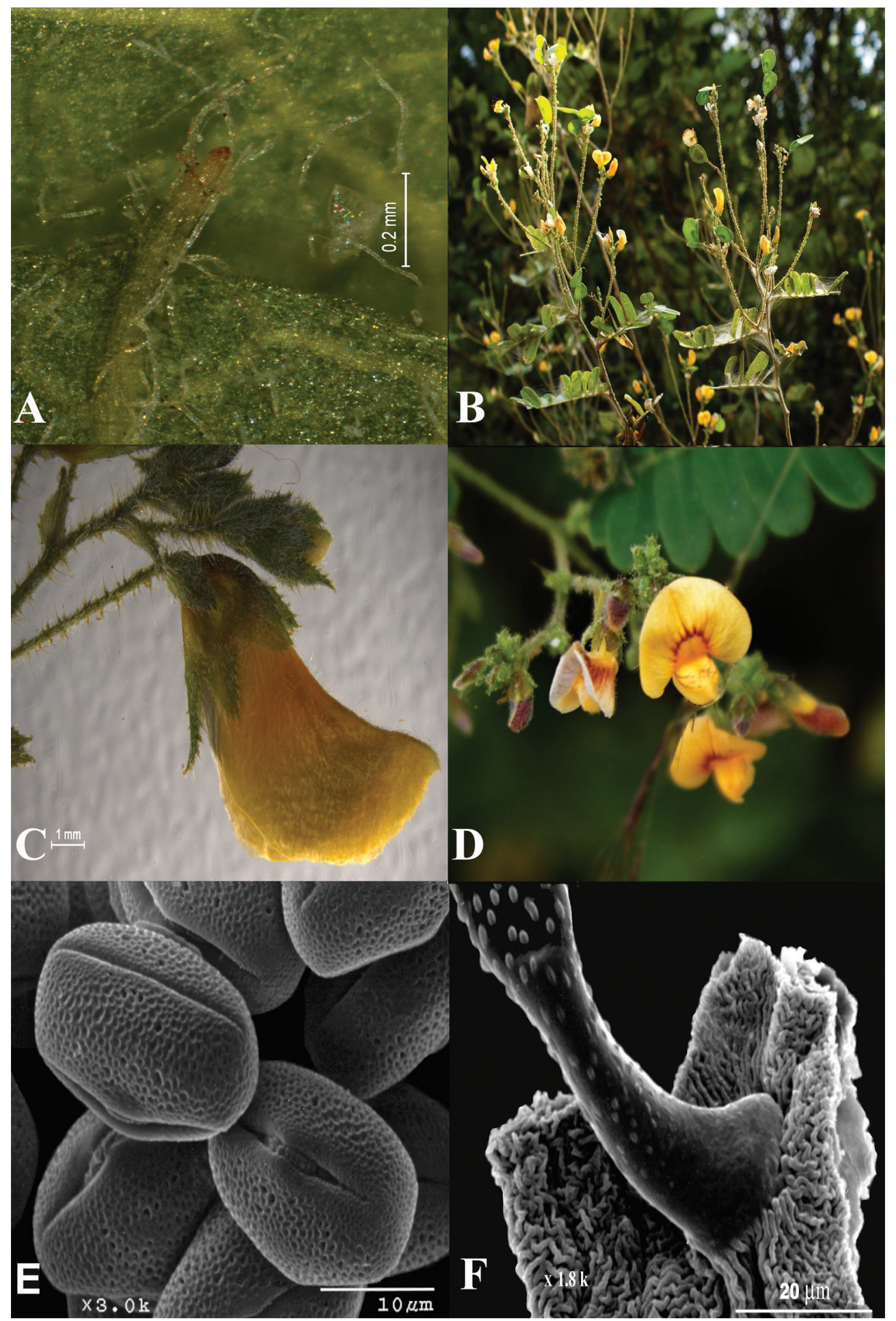

Figure 2. A, leaflet mucro, note the yellow-brown tip. B, terminal infrutescences with 2-articled loments. C, portion of inflorescence, showing bracts, bracteoles and flower buds, note the indumentum with intermixed gland-based setae. D, inflorescence with flower, note the reddish arched insect guide on standard. E, SEM showing pollen micrograph in equatorial view, pollen tricolporate, prolate, exine with reticulate sculpturing, narrow colpi with endoaperture covered by a coarsely granular operculum. F, ovary stipe covered with developing glandular-based trichomes. Photographs A and C taken by ADS; B and D taken by SS; E and F taken by BMG (IBUNAM). 
never formally published. With great pleasure we follow the intention of Dr. Rudd and now formalize the name Aeschynomene sousae for the leading Mexican botanist, Dr. Mario Sousa Sánchez for his major contributions to Mexican Leguminosae, particularly for the state of Oaxaca.

Taxonomic remarks. Aeschynomene sousae is here placed in subgenus Ochopodium, series Scopariae, due to its morphological similarity with other species of this series. It is in many ways most similar to Aeschynomene nicaraguensis (Oerst.) Standl., but it differs in density and composition of the indumentum, the length of bracteoles, flower color, the peculiar upper margin connation of the wing petals, and in ovule number. Indumentum in $A$. sousae tends to be less profuse than in A. nicaraguensis, but especially distinctive by the presence of more gland-based setae on the petioles, peduncles, pedicels, bracts, bracteoles, calyx teeth and distal portion of fruit stipe. Bracts and particularly bracteoles are slightly larger and lanceolate in A. sousae (bracteoles 2-3 mm long) than in A. nicaraguensis (bracteoles ovate, ca. $1.5 \mathrm{~mm}$ long). Flowers of $A$. sousae are bright yellow to orange-yellow, the standard petal internal face with a reddish arched insect guide-mark, on the lower half, surrounding a central dull yellow area, whereas those of A. nicaraguensis are dull orange yellow, with the internal face deep maroon or purplish-veined, mostly in the upper half of the lamina (refer to the flower image on www. Tropicos.org, photo $\mathrm{MBG}$, for distinctive flower color and standard pigmentation pattern), fading to somewhat purple in herbarium specimens. An outstanding characteristic of $A$. sousae is the distinctive fusion of the wing petals along part of their upper margins. This, to the best of our knowledge, has not been reported for any other species of the genus Aeschynomene. Fruits in A. sousae bear 1 to 2 seeds, whereas those of A. nicaraguensis have mostly 3 seeds. Moreover, the habitat preferences of these 2 species are distinct. A. sousae seems to be restricted to the tropical deciduous or scrub forests of the Sierra Madre del Sur (southern Oaxaca), at lower to mid elevations, between 45 to $1085 \mathrm{~m}$. It is normally found in ravines, where it blooms from August to November. Plants of A. nicaraguensis, on the other hand, occur in Guatemala, El Salvador, Honduras and Nicaragua and are found on drier slopes or in canyons on rich volcanic soils, in scattered patches of seasonally dry tropical forest, oak forest and riparian forest between 110 to $1700 \mathrm{~m}$. The flowering season of A. nicaraguensis is more extended, occurring from June to January, with fruiting from October to March.

\section{Acknowledgements}

We are grateful to M. R. García Peña of the National Herbarium (MEXU) for her assistance in dealing with specimen loans. Leticia Torres Colín, Susana Guzmán Gómez and Berenit Mendoza Garfias provided technical assistance with herbarium collections, light microscopy and SEM facilities, respectively. The illustration is by the accomplished hand of Albino Luna. We thank Fernando Chiang for translating the species diagnosis to Latin. Also, the very thoughtful comments made by Gwilym P. Lewis and Matt Lavin are gratefully acknowledged. Fieldwork was supported by UNAM-DGAPA, PAPIIT IN222109.

\section{Literature cited}

Fernandes, A. 1996. O táxon Aeschynomene no Brasil. Fortaleza: EUFC. Brasil. 127 p.

Rudd, V. E. 1955. The American species of Aeschynomene. Contributions U.S. National Herbarium 32:1-172.

Rudd, V. E. 1975. Supplementary studies in Aeschynomene III: Series Scopariae in Mexico and Central America. Phytologia 31:431-434.

Rudd, V. E. 1989. A new species and reconsiderations in Aeschynomene series Scopariae (Leguminosae, Papilionoideae) in Mexico. Acta Botanica Mexicana 8:31-33.

Sousa, M., R. Medina, G. Andrade and M. L. Rico. 2004. Leguminosas. In Biodiversidad de Oaxaca, A. J. GarcíaMendoza, M. J. Ordóñez y M. Briones-Salas (eds.). Instituto de Biología, UNAM, Fondo de la Conservación de la Naturaleza, World Wildlife Fund, México. p. 249-269. 